\title{
Florence Hellot-Bellier. Chronique de massacres annoncés. Les Assyro-Chaldéens d'Iran et du Hakkari face aux ambitions des empires (1896-1920)
}

Christelle Jullien

\author{
(2) OpenEdition \\ Journals \\ Édition électronique \\ URL : http://journals.openedition.org/abstractairanica/43108 \\ DOI : 10.4000/abstractairanica.43108 \\ ISBN : 1961-960X \\ ISSN : 1961-960X \\ Éditeur : \\ CNRS (UMR 7528 Mondes iraniens et indiens), Éditions de l'IFRI
}

\section{Référence électronique}

Christelle Jullien, «Florence Hellot-Bellier. Chronique de massacres annoncés. Les Assyro-Chaldéens d'ran et du Hakkari face aux ambitions des empires (1896-1920) ", Abstracta Iranica [En ligne], Volume 37-38-39 | 2018, document 2, mis en ligne le 30 décembre 2018, consulté le 28 septembre 2020. URL : http://journals.openedition.org/abstractairanica/43108; DOI : https://doi.org/10.4000/ abstractairanica.43108

Ce document a été généré automatiquement le 28 septembre 2020.

Tous droits réservés 


\title{
Florence Hellot-Bellier. Chronique de massacres annoncés. Les Assyro- Chaldéens d'Iran et du Hakkari face aux ambitions des empires (1896-1920)
}

\author{
Christelle Jullien
}

\section{RÉFÉRENCE}

Florence Hellot-Bellier. Chronique de massacres annoncés. Les Assyro-Chaldéens d'Iran et du Hakkari face aux ambitions des empires (1896-1920). Paris : Geuthner, 2014, 710 p. (Cahiers d'études syriaques 2), ISBN 9782705339012.

1 Ce livre très documenté présente une mise en contexte très fine des différentes étapes qui conduisirent aux massacres perpétrés en 1915 et 1918 à l'encontre des chrétiens assyro-chaldéens et arméniens de la région d'Ourmia en Azerbaïdjan, à l'Est de la Turquie et au Nord-Ouest de l'Iran. Il en décrit aussi les conditions en resituant les forces en présence sur le terrain et les enjeux nationaux et internationaux antagonistes qui aboutirent à une progressive montée de la violence du Caucase à l'Anatolie orientale: la faiblesse des gouvernements iraniens, l'arrivée au pouvoir des Jeunes Turcs et les revendications nationalistes fragilisèrent une coexistence ancienne des populations. De même, les incursions agressives des empires ottoman, britannique et russe et les traités partiaux ont suscité des sentiments de spoliation et de frustration. L'A. analyse aussi les tentatives des chrétiens pour apaiser et conjurer la dégradation inexorable de la situation. En 1914, avec l'entrée en guerre de l'empire ottoman aux côtés de la Triple-Alliance, la décision du patriarche assyro-chaldéen d'engager les tribus assyriennes du Hakkari au côté des Russes devait avoir des répercussions dramatiques pour cette communauté, car les «organisations spéciales " ottomanes perpétrèrent alors une élimination systématique des chrétiens de la région, entraînant un exode massif. Les massacres de 1915 de part et d'autre de la frontière irano-turque, 
puis de 1918 et 1919, firent basculer les solidarités tribales séculaires entre Assyriens et Kurdes ottomans. Si ces années tragiques ont douloureusement marqué la mémoire des chrétiens assyro-chaldéens et arméniens de l'Est de la Turquie et de l'Iran, elles ont aussi provoqué la disparition de la présence assyrienne au Hakkari. L'A. achève son bel ouvrage sur une note plus optimiste en relevant l'amorce d'un "vivre ensemble" à partir de 1920 entre musulmans et chrétiens iraniens d'Ourmia et de Salmas. De nombreuses figures et cartes viennent illustrer le propos.

\section{AUTEURS}

CHRISTELLE JULLIEN

CNRS, Mondes iranien et indien, Paris 